\title{
Gas exchange, leaf and root dry mass in Bell Pepper under fertigation with nitrogen and potassium
}

\section{Trocas gasosas, massa seca de folhas e raízes em pimentão fertirrigado com nitrogênio e potássio}

\author{
Marcelo Zolin Lorenzoni ${ }^{1 *}$; Roberto Rezende ${ }^{2}$; \\ Álvaro Henrique Cândido de Souza ${ }^{1}$; Fernando André Silva Santos ${ }^{1}$; \\ Cláudia Salim Lozano ${ }^{1}$; Cássio de Castro Seron ${ }^{1}$
}

\begin{abstract}
Bell pepper is a vegetable-fruit of great economic importance in Brazil. Crop production demands adequate water supply, nutrients, and light. The objective of this study was to evaluate gas exchange (net photosynthesis, stomatal conductance, transpiration, internal carbon concentration and instantaneous carboxylation efficiency) and dry mass accumulation in leaves and roots under fertigation with nitrogen and potassium. The experiment was conducted in a completely randomized design in a factorial scheme $(4 \times 4)$ with four replications and a total of 64 experimental units. Treatments consisted of a combination of four nitrogen doses $\left(0 ; 73.4 ; 146.8\right.$ and $293.6 \mathrm{~kg} \mathrm{ha}^{-1}$ of $\left.\mathrm{N}\right)$ with four doses of potassium $(0 ; 53.3$; 106.7 and $213.4 \mathrm{~kg} \mathrm{ha}^{-1}$ of K). An infrared gas analyzer (IRGA) coupled with a light source (irradiation of $600 \mu \mathrm{mol} \mathrm{m} \mathrm{m}^{-2} \mathrm{~s}^{-1}$ ) was used for the evaluation of gas exchange. There was a significant interactive effect of $\mathrm{N}$ and $\mathrm{K}$ on net photosynthesis and leaf and root dry mass. Root dry mass was the variable that best expressed this interaction. Physiological variables measured were more responsive to nitrogen fertilization than to $\mathrm{K}$ fertilization. The optimum values of stomatal conductance, transpiration, internal carbon concentration and carboxylation efficiency were obtained with the application of nitrogen doses between 147 and $294 \mathrm{~kg} \mathrm{ha}^{-1}$.
\end{abstract}

Key words: Capsicum annuum L.. Cultivation in pots. Photosynthesis. Mineral nutrition.

\section{Resumo}

O pimentão é uma hortaliça-fruto de grande importância econômica no país. Em seu processo de produção a cultura demanda água, nutrientes e luz em quantidades adequadas. Este trabalho teve por objetivo avaliar as trocas gasosas (fotossíntese líquida, condutância estomática, transpiração, concentração interna de carbono e eficiência instantânea de carboxilação) e o acúmulo de massa seca das folhas e de raiz na cultura do pimentão fertirrigado com nitrogênio e potássio. O experimento foi conduzido em ambiente protegido em delineamento inteiramente casualizado com esquema fatorial $(4 \times 4)$ com quatro repetições, totalizando 64 unidades experimentais. Os tratamentos consistiram na combinação de quatro doses de nitrogênio $\left(0 ; 73,4 ; 146,8\right.$ e $293,6 \mathrm{~kg} \mathrm{ha}^{-1}$ de N) com quatro doses de potássio $\left(0 ; 53,3 ; 106,7\right.$ e 213,4 $\mathrm{kg} \mathrm{ha}^{-1}$ de K). Um analisador de gás infravermelho (IRGA) com fonte de luz acoplada (irradiação de $600 \mu \mathrm{mol} \mathrm{m}^{-2} \mathrm{~s}^{-1}$ ) foi utilizado para avaliar as trocas gasosas. Houve interação na aplicação de $\mathrm{N}$ e $\mathrm{K}$ para fotossíntese líquida, massa seca das folhas e de raiz, sendo a massa seca de raiz a variável que expressa melhor essa interação. As alterações fisiológicas são

\footnotetext{
1 Discentes de Doutorado em Agronomia, Programa de Pós-Graduação em Agronomia, Departamento de Agronomia, Universidade Estadual de Maringá, UEM, Maringá, PR, Brasil. E-mail: marcelorenzoni@hotmail.com; alvarohcs@hotmail.com; fernan.agr@ hotmail.com; claudia.lozano93@hotmail.com; cassioseron@msn.com

2 Prof. Dr., Departamento de Agronomia, UEM, Maringá, PR, Brasil. E-mail: rrezende@uem.br

* Author for correspondence
} 
mais responsivas à adubação nitrogenada quando comparada à adubação potássica. Os valores mais expressivos de condutância estomática, transpiração, concentração interna de carbono e eficiência de carboxilação foram obtidos com a aplicação de doses de nitrogênio entre 147 e $294 \mathrm{~kg} \mathrm{ha}^{-1}$.

Palavras-chave: Capsicum annuum L.. Cultivo em vasos. Fotossíntese. Nutrição mineral.

\section{Introduction}

Bell pepper (Capsicum annuum L.) stands out among the vegetables of major economic importance in Brazil, with an estimated production of 290 thousand tons of fruits per year (MAROUELLI; SILVA, 2012). Nutritional requirements can be highlighted as one of the most important factors that affect growth and productivity of vegetable crops. Fertigation is a commonly used technology to supply plant nutrition via chemical fertilizers that is becoming increasingly popular among growers because of the ease to apply nutrients together with irrigation water.

The mineral nutrients needed in largest amounts by the bell pepper crop are potassium and nitrogen (FONTES et al., 2005; ARAGÃO et al., 2012). Nitrogen is related to photosynthesis, root development, ionic absorption of other nutrients, growth and activation of respiration enzymes (MARSCHNER, 2012), while potassium is required in several biological processes in plant cells, such as enzymatic activation, respiration, photosynthesis, K-pump mechanism for opening and closing of stomata and water intake for maintenance of cell turgor; thus, potassium is intimately involved in the mechanisms that regulate water balance in the plant (PRAZERES et al., 2015).

In regard to gas exchange, stomatal movement is the main mechanism that controls this process in the leaves, due to the simultaneous influx of $\mathrm{CO}_{2}$ and efflux of water vapor, which occur through the stomata during the photosynthetic process (PRAZERES et al., 2015). The deficiency or excess of the aforementioned nutrients can hinder the gas exchange process, causing stomatal closure and the reduction of stomatal conductance and transpiration, thereby, leading to a reduction in the rate of photosynthesis. According to Andrade Júnior et al. (2011), the measurement of gas exchange contributes to the study of physiological changes in plants submitted to adverse conditions.

According to Carvalho et al. (2011), there is a growing need to estimate the productive capacity of crops in view of the possible effects caused by the changes in cultivation techniques. In this sense, it is important to determine the effect of nutritional factors on plant physiology in order to ensure greater accumulation of biomass and production.

Given these facts, this study aimed to evaluate gas exchange and accumulation of dry mass in the leaves and roots of bell pepper plants grown in pots and fertigated with different doses of nitrogen and potassium in a protected environment.

\section{Material and Methods}

The study was conducted in a protected environment at the Technical Center of Irrigation of the State University of Maringá (UEM), Maringá, PR (23 25' 57' S, 51 ${ }^{\circ} 57^{\prime} 08^{\prime \prime} \mathrm{W}$ and 542 masl), between February and August of 2015. The climate of the region is of type Cfa, according to Köppen (ALVARES et al., 2013), characterized as humid mesothermal with abundant rains in the summer and dry winters. The average temperature is $21.8^{\circ} \mathrm{C}$ and average annual rainfall is $1500 \mathrm{~mm}$.

The experiment was conducted in a completely randomized design in a factorial scheme $(4 \times 4)$ with four replications in a total of 64 experimental units. The 16 treatments were combinations of four nitrogen doses $(\mathrm{N} 1=0 ; \mathrm{N} 2=73.4 ; \mathrm{N} 3=146.8$ and $\mathrm{N} 4=293.6 \mathrm{~kg} \mathrm{ha} \mathrm{h}^{-1}$ of $\mathrm{N}$ ) and four potassium doses $(\mathrm{K} 1=0 ; \mathrm{K} 2=53.3 ; \mathrm{K} 3=106.7$ and $\mathrm{K} 4=$ $213.4 \mathrm{~kg} \mathrm{ha}^{-1}$ of $\left.\mathrm{K}\right)$, considering the maximum 
doses recommended by Trani (2014). The nutrient amounts were divided according to the absorption rate for bell pepper (FONTES et al., 2005).

The seedlings were produced in polyethylene trays filled with commercial substrate for vegetables, where seeds of the virus-resistant "Magali R" hybrid were sown. The seedlings were transplanted when they had four to six leaves at 34 days after sowing, one in each pot with a capacity for $25 \mathrm{~L}$ of soil.

The pots were filled with soil classified as Dystrophic Red Latosol (SANTOS et al., 2013), with a sandy texture and with the following physical and chemical characteristics: $780 \mathrm{~g} \mathrm{~kg}^{-1}$ of sand; 30 $\mathrm{g} \mathrm{kg}^{-1}$ of silt; $190 \mathrm{~g} \mathrm{~kg}^{-1}$ of clay; P: $8.63 \mathrm{mg} \mathrm{dm}^{-3}$; $\mathrm{Na}^{+}: 2.1 \mathrm{mg} \mathrm{dm}{ }^{-3} ; \mathrm{Ca}^{+2}: 1.56 \mathrm{cmol}_{\mathrm{c}} \mathrm{dm}^{-3} ; \mathrm{Mg}^{+2}: 0.38$ $\mathrm{cmol}_{\mathrm{c}} \mathrm{dm}^{-3} ; \mathrm{K}^{+}: 0.07 \mathrm{cmol}_{\mathrm{c}} \mathrm{dm}^{-3}$; organic matter: $4.66 \mathrm{~g} \mathrm{dm}^{-3} ; \mathrm{pH}: 4.8 ; \mathrm{Al}^{+3}: 0.7 \mathrm{cmol}_{\mathrm{c}} \mathrm{dm}^{-3}$.

Liming was performed 60 days before transplanting in order to raise soil $\mathrm{pH}$, which increased the basal saturation to $80 \%$. In the planting fertilization, $165 \mathrm{~kg} \mathrm{ha}^{-1}$ of $\mathrm{K}_{2} \mathrm{O}, 480 \mathrm{~kg} \mathrm{ha}^{-1}$ of $\mathrm{P}_{2} \mathrm{O}_{5}$ and $500 \mathrm{~g}$ plant $^{-1}$ of organic matter were applied 20 days before transplanting (TRANI, 2014).

A drip irrigation system was used with an emitter calibrated for a flow rate of $4 \mathrm{~L} \mathrm{~h}^{-1}$ in each experimental unit, to which a small tube $0.3 \mathrm{~m}$ in length was coupled. Dispensing of water was controlled by daily weighing the pots on a digital scale; when the soil moisture was close to critical (0.09 $\left.\mathrm{g} \mathrm{g}^{-1}\right)$, the soil was irrigated to replenish humidity holding capacity of the pots $\left(0.2 \mathrm{~g} \mathrm{~g}^{-1}\right)$.

An infrared gas analyzer (IRGA), (LCpro+, ADC BioScientific Ltd., UK), coupled with a light source (irradiation of $600 \mu \mathrm{mol} \mathrm{m} \mathrm{m}^{-2} \mathrm{~s}^{-1}$ ) was used for the evaluation of gas exchange. Measurements were taken from the third leaf counted from the apex of the plant at 90 days after transplanting (DAT), from 07:30 to 09:30 in the morning, during the fruiting phase. The variables measured were, net photosynthesis rate (A) ( $\mu \mathrm{mol}$ of $\left.\mathrm{CO}_{2} \mathrm{~m}^{-2} \mathrm{~s}^{-1}\right)$, stomatal conductance (gs) ( $\mathrm{mol}$ of $\mathrm{H}_{2} \mathrm{O} \mathrm{m}^{-2} \mathrm{~s}^{-1}$ ), transpiration rate $(\mathrm{E})\left(\mathrm{mmol} \mathrm{H}_{2} \mathrm{O} \mathrm{m}^{-2} \mathrm{~s}^{-1}\right)$, internal carbon concentration $(\mathrm{Ci})\left(\mu \mathrm{mol} \mathrm{m} \mathrm{m}^{-2} \mathrm{~s}^{-1}\right)$ and the relation between net photosynthesis (A) and internal carbon concentration (Ci), called instantaneous carboxylation efficiency (A/Ci) $\left(\mu \mathrm{mol} \mathrm{m}^{-2} \mathrm{~s}^{-1}\right) /$ $\left(\mu \mathrm{mol} \mathrm{m} \mathrm{m}^{-2} \mathrm{~s}^{-1}\right)$.

In addition to the evaluation of gas exchange, leaf dry mass (LDM) (g plant $\left.{ }^{-1}\right)$ and root dry mass (RDM) $\left(\mathrm{g} \mathrm{plant}^{-1}\right)$ were measured at the end of the experiment. The leaves of the plants were separated and the roots were removed from the pots and were individually washed. Both plant parts were dried in a forced air circulation oven at $65^{\circ} \mathrm{C}$ until constant mass.

The data were analyzed by multiple regression using the Sisvar software (FERREIRA, 2014). The following criteria were considered to select the model: F-test $(p<0.05)$; test not significant for lack of fit ( $>0.05)$ and adjustment of the coefficient of determination $\left(\mathrm{R}^{2}\right.$ adj). The complete model considered was $Z=\beta 0+\beta 1(X)+\beta 2(Y)+\beta 3(X)^{2}+$ $\beta 4(\mathrm{Y})^{2}+\beta 5(\mathrm{X})(\mathrm{Y})$, where $\mathrm{Z}$ is the estimated value for the characteristics studied; $\beta 0, \beta 1, \beta 2, \beta 3, \beta 4$ and $\beta 5$ are the regression coefficients and, $\mathrm{X}$ and $\mathrm{Y}$ are the variables.

\section{Results and Discussion}

Significant $(p<0.05)$ interaction was evidenced between the levels of nitrogen and potassium for the variables net photosnthesis (A), leafdry mass (LDM) and root dry mass (RDM). As for the isolated effect of each factor, there were significant responses to nitrogen from all variables under study, while only net photosynthesis (A), stomatal conductance (gs) and root dry mass $(\mathrm{RDM})$ responded significantly to the potassium doses tested in this experiment (Table $1)$. 
Table 1. Summary of the analysis of variance for net photosynthesis (A), stomatal conductance (gs), transpiration rate (E), internal $\mathrm{CO}_{2}$ concentration (Ci), carboxylation instantaneous efficiency (A/Ci), leaf dry matter (LDM) and root dry matter (RDM) for Bell Pepper crop.

\begin{tabular}{lcccccccc}
\hline Variation & \multicolumn{7}{c}{ Mean squares } \\
\cline { 2 - 9 } \multicolumn{1}{c}{ sources } & DF & $\mathrm{A}$ & gs & $\mathrm{E}$ & $\mathrm{Ci}$ & $\mathrm{A} / \mathrm{Ci}$ & $\mathrm{LDM}$ & $\mathrm{RDM}$ \\
\hline $\mathrm{N}$ & 3 & $204.6^{*}$ & $0.062^{*}$ & $3.53^{*}$ & $1430.5^{*}$ & $0.0041^{*}$ & $1921.2^{*}$ & $618.7^{*}$ \\
$\mathrm{~K}$ & 3 & $7.67^{*}$ & $0.007^{*}$ & $0.11^{\text {ns }}$ & $32.20^{\text {ns }}$ & $0.0000^{\text {ns }}$ & $11.12^{\text {ns }}$ & $23.59^{*}$ \\
$\mathrm{~N} \mathrm{x} \mathrm{K}$ & 9 & $6.03^{*}$ & $0.004^{\text {ns }}$ & $0.18^{\text {ns }}$ & $703.86^{\text {ns }}$ & $0.0001^{\text {ns }}$ & $58.52^{*}$ & $83.50^{*}$ \\
\hline Residual & 48 & 2.67 & 0.002 & 0.28 & 478.81 & 0.00007 & 5.47 & 6.93 \\
$\mathrm{CV}(\%)$ & & 15.15 & 25.86 & 28.96 & 9.00 & 19.37 & 13.44 & 12.62 \\
Average & & 10.79 & 0.19 & 1.85 & 243.00 & 0.045 & 17.40 & 20.87 \\
\hline
\end{tabular}

* significant at 0,$05 ;{ }^{\text {ns }}$ Non-significant at 0,05 .

It was not possible to fit a multiple regression $\mathrm{N}$ in the $\mathrm{K}$ levels had significant differences which model for the net photosynthesis variable (A). were fitted to the second-degree polynomial model Regression analysis revealed that only the doses of (Figure 1).

Figure 1. Net photosynthesis of Bell Pepper as a function of nitrogen aplication for each level of potassium aplicated $\left(\mathrm{K} 1=0 ; \mathrm{K} 2=53.3 ; \mathrm{K} 3=106.7\right.$ e $\mathrm{K} 4=213.4 \mathrm{~kg} \mathrm{ha}^{-1}$ of $\left.\mathrm{K}\right)$.

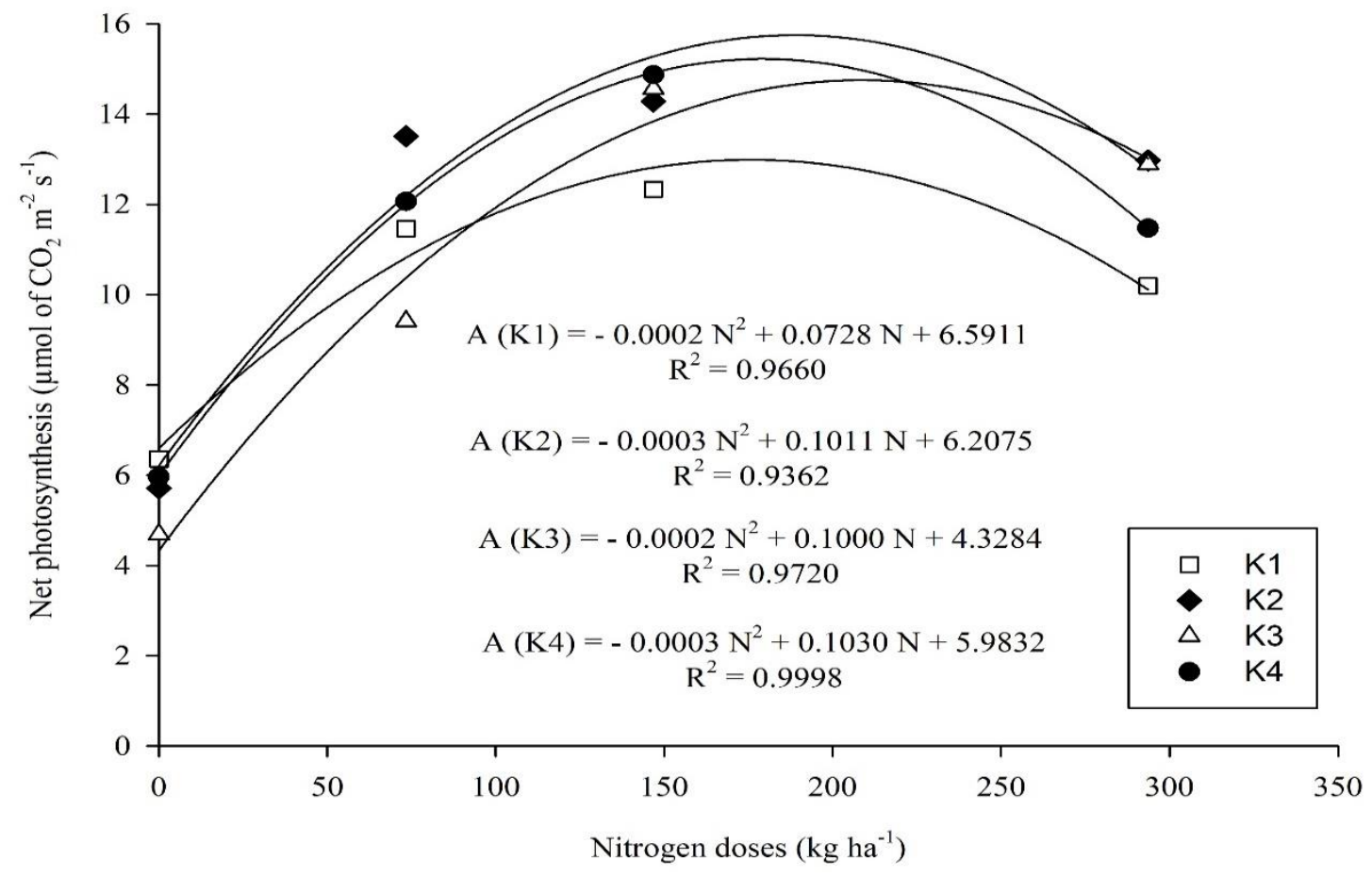


Potassium fertilization before transplanting of seedlings may have contributed to the absence of significant differences in the variables studied after $\mathrm{K}$ application by fertigation. When the soil is high in potassium, the absorption by the plant is above its metabolic amount, which accumulates in the organelles of the plant cell and can be characterized as luxury consumption; i.e., nutrient absorption by the plant is beyond optimum for development. Hence, it does not benefit the plant any further (LARCHER, 2001; MARSCHNER, 2012).

Figure 1 shows that increasing $\mathrm{N}$ promoted an increase in net photosynthesis (A) until a certain point, after which A decreased independently of the $\mathrm{K}$ dose. The smaller nitrogen doses provided lower photosynthetic rates, as reported by Broadley et al. (2001), who observed a lower photosynthetic rate in lettuce plants at low $\mathrm{N}$. The reduction of $\mathrm{A}$ may be associated with the closure of the stomata, which respond directly to the lack of nitrogen or to the increase of $\mathrm{CO}_{2}$ partial pressure inside the chloroplasts (BROADLEY et al., 2001). The maximum value of $\mathrm{A}, 14.72 \mu \mathrm{mol}$ of $\mathrm{CO}_{2} \mathrm{~m}^{-2} \mathrm{~s}^{-1}$, was estimated at level K2 (53.3 $\left.\mathrm{kg} \mathrm{ha}^{-1}\right)$ with 168.5 $\mathrm{kg} \mathrm{ha}^{-1}$ of $\mathrm{N}$, a value within the range found by Melo et al. (2017), which was 7 to $18 \mu \mathrm{mol}$ of $\mathrm{CO}_{2}$ $\mathrm{m}^{-2} \mathrm{~s}^{-1}$, with the application of water with different electrical conductivities in the bell pepper crop.

Stomatal conductance (gs) data were fitted to the quadratic model with the increment of the nitrogen doses (Figure 2A). It was not possible to fit a model for potassium because of the non-significance of the model coefficients ( $p>0.05)$. The highest value of gs $\left(0.26 \mathrm{~mol}\right.$ of $\left.\mathrm{H}_{2} \mathrm{O} \mathrm{m}^{-2} \mathrm{~s}^{-1}\right)$ was estimated at $180 \mathrm{~kg} \mathrm{ha}^{-1}$ of nitrogen. This result shows that the application of up to $180 \mathrm{~kg}$ ha-1 nitrogen by fertigation induced the opening of the stomata efficiently, which provided for an increase of photosynthesis in the bell pepper plants.

In the present study, doses above $180 \mathrm{~kg} \mathrm{ha}^{-1}$ of $\mathrm{N}$ decreased stomatal conductance because of a possible reduction of the osmotic potential of the soil solution, which interfered with the stomatal opening process. The gs data follow the same behavior as the photosynthetic rate, thus, leading to the same conclusion previously mentioned, i.e., a decrease of stomatal conductance can reduce photosynthesis because of a decrease in $\mathrm{CO}_{2}$ partial pressure in the intercellular space (BROADLEY et al., 2001).

The transpiration rate data (E) followed the same trend as stomatal conductance data (Figure 2B), something that was also observed by Prazeres et al. (2015) in cowpea plants under saline irrigation and potassium supply, and by Silva et al. (2015) in eggplants under different irrigation levels. According to Lima et al. (2010), the opening and closing of the stomata determine the transpiration by the leaves, which lose water to the environment as water vapor. Marques et al. (2009) verified a positive relation between transpiration and photosynthesis in oregano plants submitted to different irrigation levels.

As explained by $\mathrm{Lu}$ et al. (2005), when evaluating forms and amounts of nitrogen in tobacco, a reduction of stomatal conductance was observed with the application of ammonium and nitrate, especially in the new leaves and at the top of the plants when ammonium was applied, suggesting that this reduction also decreases foliar transpiration because of a possible hormonal alteration (ABA increase) that would decrease stomatal conductance. As for nitrate, the reduction in conductance is lower at a low dose of $\mathrm{N}$, when compared to high doses. The results obtained in the present study are possibly attributable to the source of $\mathrm{N}$ used, changing the amounts and forms of $\mathrm{N}$ (ammonium nitrate) in the plant, which also resulted in physiological changes.

Maximum transpiration rate $\left(2.36 \mathrm{mmol}_{2} \mathrm{O}\right.$ $\mathrm{m}^{-2} \mathrm{~s}^{-1}$ ) was estimated at $174.5 \mathrm{~kg} \mathrm{ha}^{-1}$ of $\mathrm{N}$, which is an amount close to that required to attain maximum stomatal conductance $\left(180 \mathrm{~kg} \mathrm{ha}^{-1}\right.$ of $\left.\mathrm{N}\right)$. Larger doses, caused $\mathrm{E}$ and gs to decrease. The decrease of the stomatal conductance is directly related to the reduction in the transpiration rate, that is, when 
there are smaller stomatal openings, there will be a decrease in transpiration and an increase in leaf temperature (MACHADO et al., 2005; PINTO et al., 2008).

The internal carbon concentration $(\mathrm{Ci})$ showed a decreasing quadratic trend with the increase of $\mathrm{N}$, a behavior similar to that observed by Andrade Júnior et al. (2011) for melon, while Silva et al. (2015) obtained an increasing linear trend in eggplant under different irrigation levels. The lowest value of $\mathrm{Ci}$, equivalent to $234.5 \mu \mathrm{mol} \mathrm{m} \mathrm{m}^{-2} \mathrm{~s}^{-1}$, was estimated at $216 \mathrm{~kg} \mathrm{ha}^{-1}$ of $\mathrm{N}$ (Figure 2C). While there was reduction of $\mathrm{Ci}$, there was an increase of photosynthesis. According to Andrade Júnior et al. (2011), this behavior demonstrates a greater efficiency in the use of $\mathrm{CO}_{2}$ that enters the cell, since a lower availability of carbon was associated with greater accumulation of biomass in this case.

Figure 2. Stomatal conductance (A); Transpiration rate (B); internal $\mathrm{CO}_{2}$ concentration (C) and instantaneous carboxylation efficiency (D) of Bell Pepper as a function of nitrogen aplication.
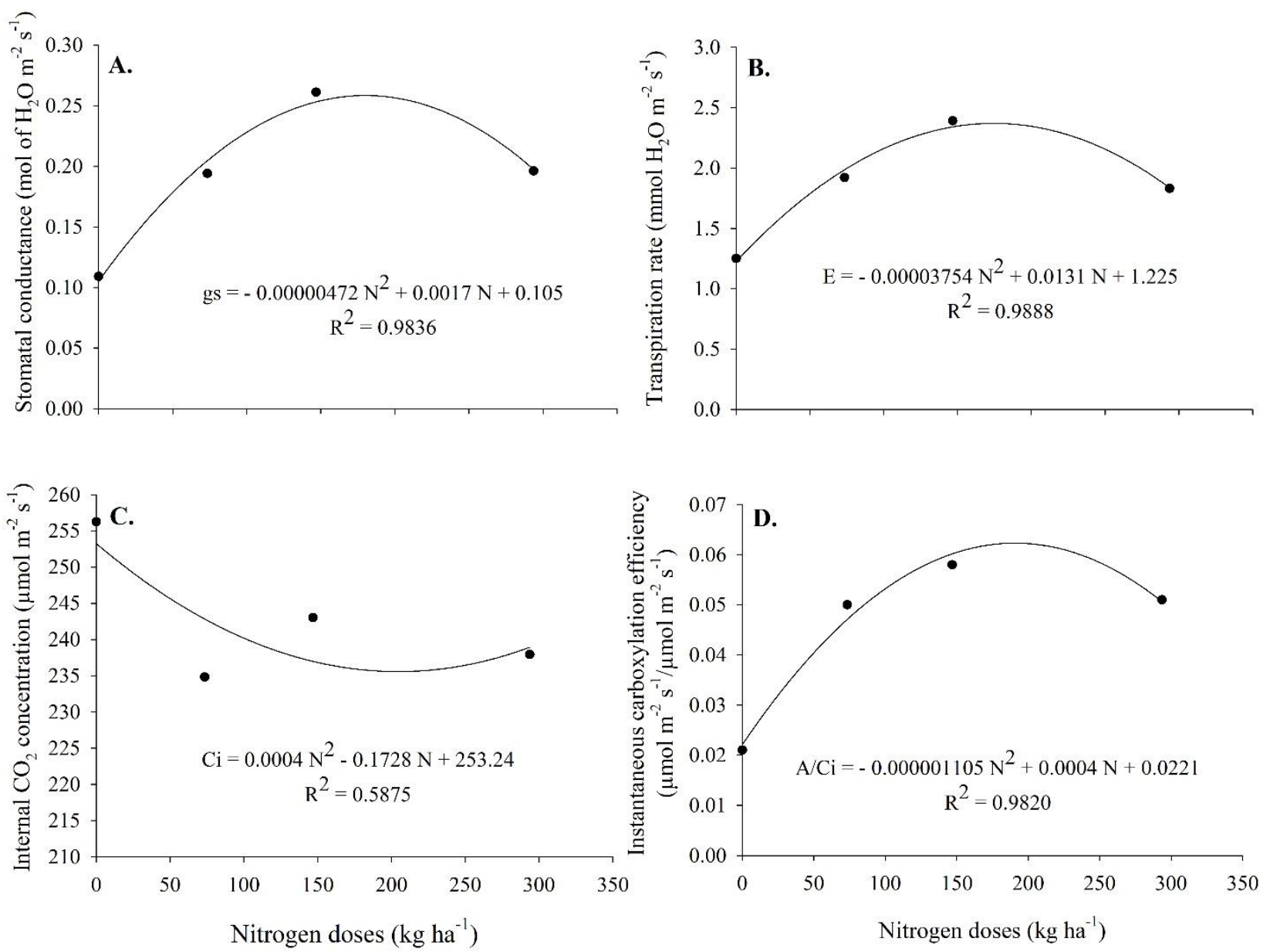

From an estimated dose of $216 \mathrm{~kg} \mathrm{ha}^{-1}$ of $\mathrm{N}$, This behavior demonstrates that the reduction of the internal $\mathrm{CO}_{2}$ concentration was not assimilated the photosynthetic process depends not only on the into the photosynthesis process, even if available. reduction of the stomata opening, but also on the 
structure of the cells responsible for the assimilation of $\mathrm{CO}_{2}$, possibly caused by the reduction in the osmotic-hydraulic potential and the accumulation of ions outside the range tolerated by the crop (ANDRADE JÚNIOR et al. 2011). If the values of $\mathrm{Ci}$ are very low, $\mathrm{CO}_{2}$ entry into the mesophyll cells is limited, so there is a limitation of the photosynthetic rate because the plant uses $\mathrm{CO}_{2}$ from the respiration to maintain a minimum level of assimilation (TAIZ; ZEIGER, 2013; MELO et al., 2017).

The value of the instantaneous carboxylation efficiency (A/Ci) increased up to $180.9 \mathrm{~kg} \mathrm{ha}^{-1}$ of $\mathrm{N}$, from which point it started to decrease, and was then better fitted into the quadratic model. The maximum estimated value of $\mathrm{A} / \mathrm{Ci}$ was $0.058 \mu \mathrm{mol}$ $\mathrm{m}^{-2} \mathrm{~s}^{-1} / \mu \mathrm{mol} \mathrm{m} \mathrm{m}^{-2} \mathrm{~s}^{-1}$. According to Silva et al. (2015), high values of $\mathrm{Ci}$ associated with an increase of gs indicate increase in $\mathrm{A} / \mathrm{Ci}$ because of the availability ofATP and NADPH. However, even at decreasing $\mathrm{Ci}$ values, the values of $\mathrm{A} / \mathrm{Ci}$ found in the present study followed the same behavior as data on A, because of the nitrogen application. Melo et al. (2017) obtained similar results for $\mathrm{A} / \mathrm{Ci}$ and $\mathrm{Ci}$. According to these authors, the instantaneous carboxylation efficiency has a close relation with $\mathrm{CO}_{2}$ assimilation rate and the intracellular concentration of $\mathrm{CO}_{2}$.

Silva et al. (2015) report that $\mathrm{A} / \mathrm{Ci}$ is dependent on the availability of $\mathrm{CO}_{2}$ in the mesophyll of the leaf, but for photosynthesis to proceed, adequate light radiation, temperature and enzymatic activity are also necessary, indicating that photosynthetic rate is also regulated by non-stomatal factors, which may by reflected as a change in $\mathrm{A} / \mathrm{Ci}$.

During an evaluation of nitrogen and potassium doses by fertigation in banana plants, Melo et al. (2009) recorded a close relation between photosynthesis and internal carbon concentration. Furthermore, $\mathrm{A} / \mathrm{Ci}$ increased with increasing $\mathrm{N}$ in relation to plants without nitrogen fertigation. However, high $\mathrm{N}$ doses reduced $\mathrm{A} / \mathrm{Ci}$, which according to the authors is possibly explained by increased oxygenase activity by Rubisco at the expense of carboxylation, leading to a lower rate of carbon assimilation even at high nitrogen availability.

It was not possible to fit a multiple regression model for leaf dry mass (LDM). Regression analysis showed that $\mathrm{N}$ doses showed significant differences in LDM at each level of $\mathrm{K}$ tested, which fitted to the quadratic model; similarly, there were no significant differences in LDM at the tested $\mathrm{K}$ doses at each $\mathrm{N}$ level (Figure 3).

The $\mathrm{N}$ dose that resulted in highest LDM varied according to the level of $\mathrm{K}$ applied by fertigation, with the maximum estimated value (34.15 g plant $^{-1}$ ) at level K3, when $173.7 \mathrm{~kg} \mathrm{ha}^{-1}$ of $\mathrm{N}$ were applied. Aragão et al. (2011), working with irrigation and nitrogen levels in bell pepper, observed that the leaf dry mass increased with the increasing nitrogen.

A shortage of $\mathrm{N}$ decreases leaf size, because of the smaller number of cells, which consequently decreases leaf dry mass and also reduces photosynthetic rate (MALAVOLTA, 2006). According to the same author, excessive nitrogen or an imbalance with other macro or micronutrient may have detrimental effects on plant performance which may be traced to physiological imbalance.

As for root dry mass (RDM), it was possible to fit a multiple regression model with $\mathrm{N}$ and $\mathrm{K}$. In order to obtain the maximum value of RDM $\left(26.67 \mathrm{~g} \mathrm{plant}^{-1}\right), 125.2 \mathrm{~kg} \mathrm{ha}^{-1}$ of $\mathrm{N}$ and $213.4 \mathrm{~kg}$ $\mathrm{ha}^{-1}$ of $\mathrm{K}$ were needed. However, potassium doses below $213.4 \mathrm{~kg} \mathrm{ha}^{-1}$ did not decrease the maximum value of RDM registered, as can be observed on the surface values (Figure 4). This effect can be explained by the addition of potassium to the pots before transplanting the bell pepper seedlings. As previously mentioned, high potassium content in the soil contributes to the plant absorption of this nutrient over the amount needed, which is characterized as luxury consumption, which results in an increase in plant growth variables. 
Figure 3. Leaf dry mass of Bell Pepper as a function of nitrogen aplication for each level of potassium aplicated (K1 $=0 ; \mathrm{K} 2=53.3 ; \mathrm{K} 3=106.7$ e $\mathrm{K} 4=213.4 \mathrm{~kg} \mathrm{ha}^{-1}$ of $\mathrm{K}$ ).

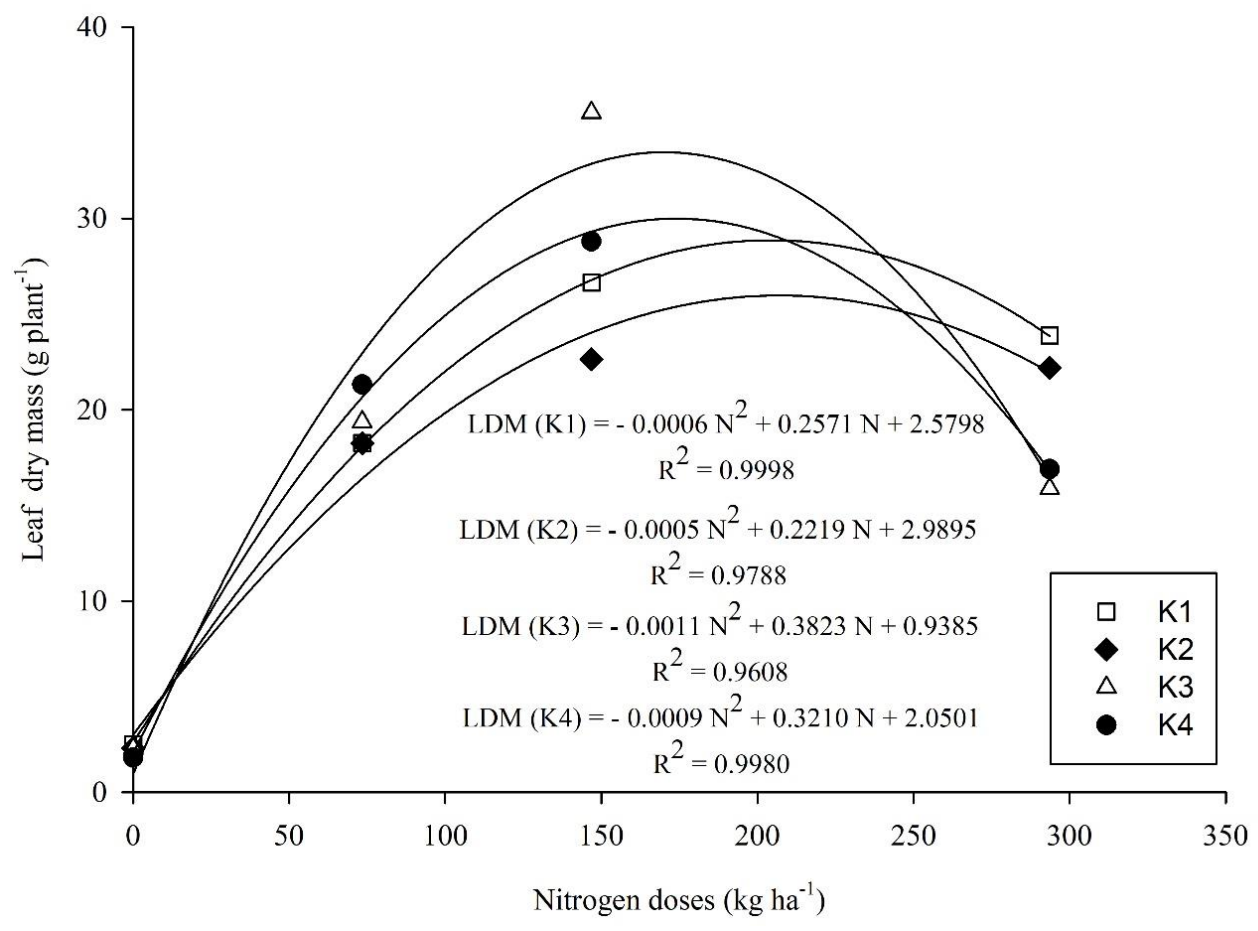

Figure 4. Root dry mass of Bell Pepper as a function of nitrogen $\left(\mathrm{N} 1=0 ; \mathrm{N} 2=73.4\right.$; N3 = 146.8 e N4 $=293.6 \mathrm{~kg} \mathrm{ha}^{-1}$ of $\mathrm{N})$ and potassium $\left(\mathrm{K} 1=0 ; \mathrm{K} 2=53.3 ; \mathrm{K} 3=106.7 \mathrm{e} \mathrm{K} 4=213.4 \mathrm{~kg} \mathrm{ha}^{-1}\right.$ of $\left.\mathrm{K}\right)$ aplication.

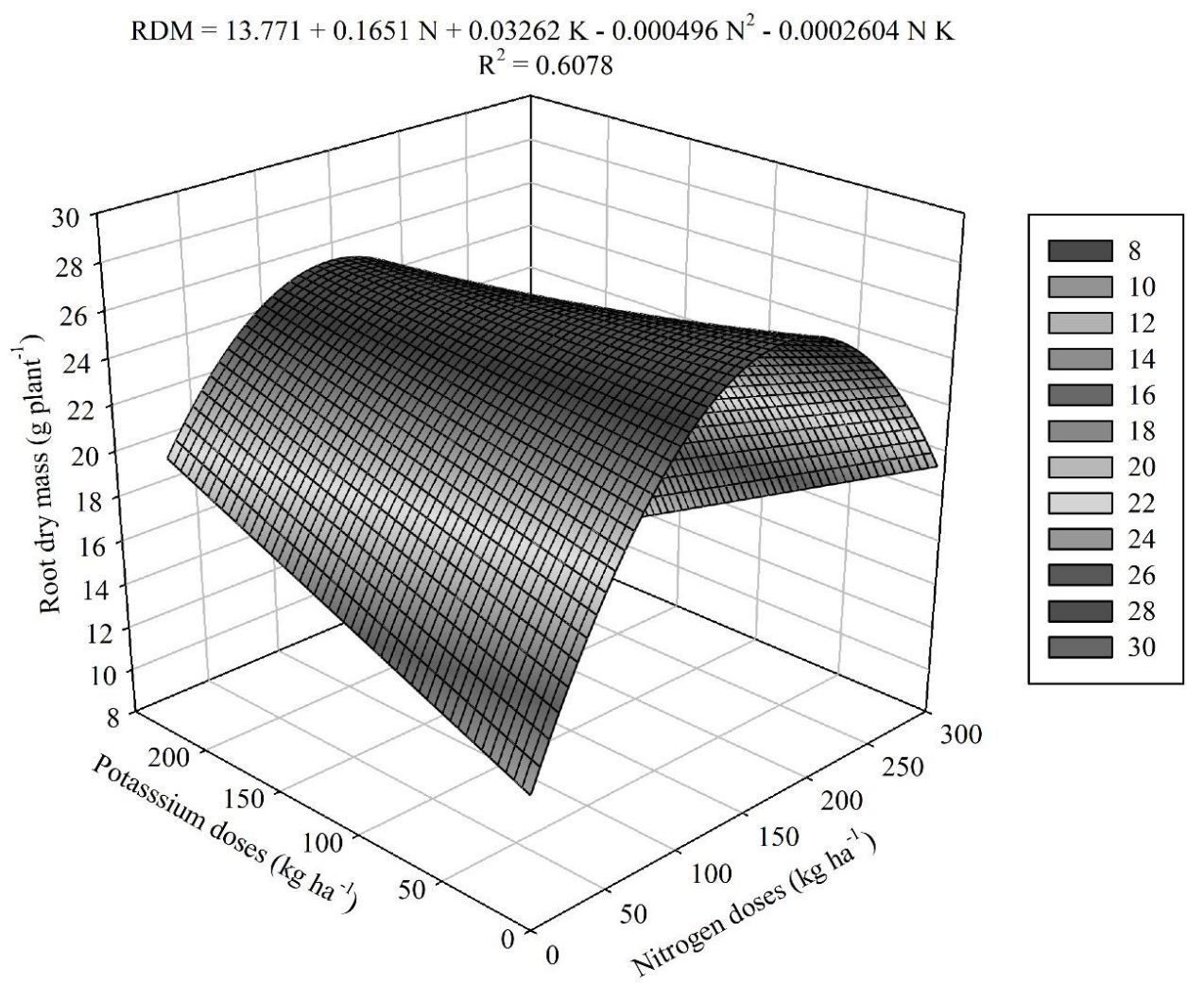


There was an increasing linear trend with increasing potassium at $0 \mathrm{~kg} \mathrm{ha}^{-1}$ of nitrogen, whereas at the maximum $\mathrm{N}$ dose $\left(293.6 \mathrm{~kg} \mathrm{ha}^{-1}\right)$, there was a decreasing linear trend with the application of K. According to López (1988), excess of nitrogen causes an imbalance between shoot and root growth, while Lavres Junior et al. (2010) states that nitrogen metabolism requires adequate amounts of $\mathrm{K}$ in the cellular cytoplasm, which demonstrates the close interaction between these nutrients.

The interaction between the root system and nutrients is complex and, as previously suggested, this interaction might be associated with the source and quantity of the nutrient for the present study. Marschner (2012) states that nutrient supply can strongly alter root growth and morphology, where the most significant effect is found with $\mathrm{N}$ supply, resulting in an increase in root area, which is often more distinct with ammonium supply, in comparison with nitrate supply.

The same interaction for root system variables has already been investigated and confirmed by other studies on other crops, which are generally responsive to potassium and nitrogen fertilization, as shown by Lavres Junior and Monteiro (2003), by applying nitrogen and potassium in a nutrient solution to a Guinea grass crop. These authors observed changes in total root length and root surface, proving that $\mathrm{N}$ was the main nutrient to which these variables respond.

There are not many studies that evaluate the dry mass of the root system of bell pepper plants. Silva et al. (1999) applied nitrogen and potassium on the soil surface to evaluate yield and bell pepper fruit quality. They verified that at all depths sampled, there was a higher growth of roots in the treatments with $\mathrm{N}$, while $\mathrm{K}$ attenuated this effect. The authors interpreted that high doses of $\mathrm{K}$ applied as potassium chloride decreased root growth because of the high saline content of this fertilizer, which can cause cellular leakage in the roots.

\section{Conclusions}

Under the conditions of this study, the physiological changes in the bell pepper crop are more responsive to nitrogen fertilization when compared to potassium fertilization.

The most significant values for the stomatal conductance, transpiration, internal carbon concentration and carboxylation efficiency variables are obtained between 147 and $294 \mathrm{~kg} \mathrm{ha}^{-1}$ of nitrogen.

Despite the interaction observed between $\mathrm{N}$ and $\mathrm{K}$, net photosynthesis and leaf dry mass were affected to a larger extent by the application of nitrogen than by application of potassium. However, root dry mass was the variable that best expressed the interaction between the doses of nitrogen and potassium tested in this study.

\section{References}

ALVARES, C. A.; STAPE, J. L.; SENTELHAS, P. C.; GONÇALVES, J. L. de M.; SPAROVEK, G. Köppen's climate classification map for Brazil. Meteorologische Zeitschrift, Stuttgart, v. 22, n. 6, p. 711-728, 2013.

ANDRADE JÚNIOR, W. P.; PEREIRA, F. H. F.; FERNANDES, O. B.; QUEIROGA, R. C. F.; QUEIROGA, F. M. Efeito do nitrato de potássio na redução do estresse salino no meloeiro. Revista Caatinga, Mossoró, v. 24, n. 3, p. 110-119, 2011.

ARAGÃO, V. F.; FERNANDES, P. D.; GOMES FILHO, R. R.; CARVALHO, C. M. de; FEITOSA, H. O.; FEITOSA, E. O. Produção e eficiência no uso de água do pimentão submetido a diferentes lâminas de irrigação e níveis de nitrogênio. Revista Brasileira de Agricultura Irrigada, Fortaleza, v. 6, n. 3, p. 207-216, 2012.

ARAGÃO, V. F.; FERNANDES, P. D.; GOMES FILHO, R. R.; SANTOS NETO, A. M.; CARVALHO, C. M. de; FEITOSA, H. O. Efeito de diferentes lâminas de irrigação e níveis de nitrogênio na fase vegetativa do pimentão em ambiente protegido. Revista Brasileira de Agricultura Irrigada, Fortaleza, v. 5, n. 4, p. 361-375, 2011.

BROADLEY, M. R.; ESCOBAR-GUTIÉRREZ, A. J.; BURNS, A.; BUNS, I. G. Nitrogen-limeted growth of lettuce is associated with lower stomatal conductance. New Phytologist, Lancaster, v. 152, n. 1, p. 97-106, 2001. 
CARVALHO, D. F.; OLIVEIRA, A. D.; PEREIRA, J. B. A. Ajuste de modelos para estimative do índice de área foliar e acúmulo de biomassa do pimentão em função de graus-dias. Semina: Ciências Agrárias, Londrina, v. 32, n. 3, p. 971-982, 2011.

FERREIRA, D. F. Sisvar : a Guide for its Bootstrap procedures in multiple comparisons. Ciência $e$ Agrotecnologia, Lavras, v. 38, n. 2, p. 109-112, 2014.

FONTES, P. C. R.; DIAS, E. N.; GRAÇA, R. N. Acúmulo de nutrientes e método para estimar doses de nitrogênio e potássio na fertirrigação do pimentão. Horticultura Brasileira, Brasília, v. 23, n. 2, p. 275-280, 2005.

LARCHER, W. Physiological plant ecology. Ecophysiology and stress physiology of functional groups. $4^{\text {th }}$ ed. English translation from 2003 SpringerVerlag, Berlin. New York: Springer, 2001. 514 p.

LAVRES JUNIOR, J.; MONTEIRO, F. A. Perfilhamento, área foliar e sistema radicular do capim-mombaça submentido a combinações de doses de nitrogênio e potássio. Revista Brasileira de Zootecnia, Viçosa, v. 32, n. 5, p. 1068-1075, 2003.

LAVRES JUNIOR, J.; SANTOS JUNIOR, J. D. G.; MONTEIRO, F. A. Nitrate reductase activity and spad readings in leaf tissues of guinea grass submitted to nitrogen and potassium rates. Revista Brasileira de Ciência do Solo, Viçosa, v. 34, n. 3, p. 801-809, 2010.

LIMA, M. A.; BEZERRA, M. A.; GOMES FILHO, E.; PINTO, C. M.; ENÉAS FILHO, J. Trocas gasosas em folhas de sol e sombreadas de cajueiro anão em diferentes regimes hídricos. Revista Ciência Agronômica, Fortaleza, v. 41, n. 4, p. 654-663, 2010.

LÓPEZ, C. C. Fertilización em Riego por goteo de cultivo hortícolas. Madrid: Delegación de Agricultura Almeria Rafael Jimenes Mijias, 1988. 213 p.

LU, Y. X.; LI, C. J.; ZHANG, F. S. Transpiration, potassium uptake and flow in tabacco as affected by nitrogen forms and nutrient levels. Annals of Botany, Oxford, v. 95, n. 6, p. 991-998, 2005.

MACHADO, E. C.; SCHMIDT, P. T.; MEDINA, C. L.; RIBEIRO, R. V. Respostas da fotossíntese de três espécies de citros a fatores ambientais. Pesquisa Agropecuária Brasileira, Brasília, v. 40, n. 12, p. 1161-1170, 2005.

MALAVOLTA, E. Manual de nutrição mineral de plantas. São Paulo: Editora Agronômica Ceres, 2006. $638 \mathrm{p}$.

MAROUELLI, W. A.; SILVA, W. L. C. Irrigação na cultura do pimentão. Brasília: EMBRAPA, 2012. 20 p. (Circular técnica, 101).
MARQUES, P.A. A.; BERNARDI FILHO, L.; SANTOS, A. C. P. Crescimento, produção de óleo essencial e trocas gasosas em orégano influenciados por diferentes lâminas de irrigação. Ciência Rural, Santa Maria, v. 39, n. 6, p. 1888-1892, 2009.

MARSCHNER, H. Mineral nutrition of higher plants. $3^{\text {th }}$ ed. London: Academic Press, 2012. 651 p.

MELO, A. S.; SILVA JÚNIOR, C. D.; FERNANDES, P. D.; SOBRAL, L. F.; BRITO, M. E. B.; DANTAS, J. D. M. Alterações das características fisiológicas da bananeira sob condições de fertirrigação. Ciência Rural, Santa Maria, v. 39, n. 3, p. 733-741, 2009.

MELO, H. F.; SOUZA, E. R.; DUARTE, H. H. F.; CUNHA, J. C.; SANTOS, H. R. B. Gas exchange and photosynthetic pigments in bell pepper irrigated with saline water. Revista Brasileira de Engenharia Agrícola e Ambiental, Campina Grande, v. 21, n. 1, p. 38-43, 2017.

PINTO, C. M.; TÁVORA, F. J. F. A.; BEZERRA, M. A.; CORRÊA, C. M. Crescimento, distribuição do sistema radicular em amendoim, gergelim e mamona a ciclos de deficiência hídrica. Revista Ciência Agronômica, Fortaleza, v. 39, n. 3, p. 429-436, 2008.

PRAZERES, S. S.; LACERDA, C. F.; BARBOSA, F. E. L.; AMORIM, A. V.; ARAÚJO, I. C. S.; CAVALCANTI, L. F. Crescimento e trocas gasosas de plantas de feijãocaupi sob irrigação salina e doses de potássio. Revista Agroambiente On-line, Boa Vista, v. 9, n. 2, p. 111-118, 2015.

SANTOS, H. G. dos; JACOMINE, P. K. T.; ANJOS, L. H. C. dos; OLIVEIRA, V. A. de; LUMBRERAS, J. F.; COELHO, M. R.; ALMEIDA, J. A. de; CUNHA, T. J. F.; OLIVEIRA, J. B. de. Sistema brasileiro de classificação de solos. 3. ed. Brasília: EMBRAPA, 2013. 353 p.

SILVA, F. G.; DUTRA, W. F.; DUTRA, A. F.; OLIVEIRA, I. M.; FILGUEIRAS, L. M. B.; MELO, A. $\mathrm{S}$. Trocas gasosas e fluorescência da clorofila em plantas de berinjela sob lâminas de irrigação. Revista Brasileira de Engenharia Agrícola e Ambiental, Campina Grande, v. 19, n. 10, p. 946-952, 2015.

SILVA, M. A. G.; BOARETTO, A. E.; MELO, A. M. T.; FERNANDES, H. M. G.; SCIVITTARO, W. B. Rendimento e qualidade de frutos de pimentão cultivado em ambiente protegido em função do nitrogênio e potássio aplicados em cobertura. Scientia Agricola, Piracicaba, v. 56, n. 4, p. 1199-1207, 1999.

TAIZ, L.; ZEIGER, E. Fisiologia vegetal. 5. ed. Porto Alegre: Artmed, 2013. 918 p.

TRANI, P. E. Calagem e adubação para hortaliças sob cultivo protegido. Campinas: Instituto Agronômico de Campinas, Centro de Horticultura, 2014. 25 p. 